\title{
Inhibition of coral recruitment by macroalgae and cyanobacteria
}

\author{
Ilsa B. Kuffner ${ }^{1, *}$, Linda J. Walters ${ }^{2}$, Mikel A. Becerro ${ }^{3}$, Valerie J. Paul ${ }^{3}$, \\ Raphael Ritson-Williams ${ }^{3}$, Kevin S. Beach ${ }^{4}$ \\ ${ }^{1}$ US Geological Survey, Center for Coastal \& Watershed Studies, 600 4th Street South, St. Petersburg, Florida 33701, USA \\ ${ }^{2}$ University of Central Florida, Department of Biology, 4000 Central Florida Boulevard, Orlando, Florida 32816, USA \\ ${ }^{3}$ Smithsonian Marine Station at Fort Pierce, 701 Seaway Drive, Fort Pierce, Florida 34949, USA \\ ${ }^{4}$ University of Tampa, Department of Biology, 401 W Kennedy Boulevard, Tampa, Florida 33606, USA
}

\begin{abstract}
Coral recruitment is a key process in the maintenance and recovery of coral reef ecosystems. While intense competition between coral and algae is often assumed on reefs that have undergone phase shifts from coral to algal dominance, data examining the competitive interactions involved, particularly during the larval and immediate post-settlement stage, are scarce. Using a series of field and outdoor seawater table experiments, we tested the hypothesis that common species of macroalgae and cyanobacteria inhibit coral recruitment. We examined the effects of Lyngbya spp., Dictyota spp., Lobophora variegata (J. V. Lamouroux) Womersley, and Chondrophycus poiteaui (J. V. Lamouroux) Nam (formerly Laurencia poiteaui) on the recruitment success of Porites astreoides larvae. All species but $C$. poiteaui caused either recruitment inhibition or avoidance behavior in $P$. astreoides larvae, while $L$. confervoides and $D$. menstrualis significantly increased mortality rates of $P$. astreoides recruits. We also tested the effect of some of these macrophytes on larvae of the gorgonian octocoral Briareum asbestinum. Exposure to Lyngbya majuscula reduced survival and recruitment in the octocoral larvae. Our results provide evidence that algae and cyanobacteria use tactics beyond space occupation to inhibit coral recruitment. On reefs experiencing phase shifts or temporary algal blooms, the restocking of adult coral populations may be slowed due to recruitment inhibition, thereby perpetuating reduced coral cover and limiting coral community recovery.
\end{abstract}

KEY WORDS: Allelopathy $\cdot$ Coral-algae interactions $\cdot$ Dictyota spp. $\cdot$ Lyngbya spp. $\cdot$ Phase shift

\section{INTRODUCTION}

Competition for space is an important factor structuring marine benthic communities, particularly on coral reefs (e.g. Porter 1974, Jackson \& Buss 1975). Historically, studies investigating competition for space on coral reefs focused on interactions among invertebrates (Jackson \& Buss 1975, Benayahu \& Loya 1981, Porter \& Targett 1988), as macroalgae were inconspicuous members of most coral reef communities prior to the 1980s (Dahl 1974). Since then, coral reef degradation has occurred on a global scale (Hoegh-Guldberg 1999, Knowlton 2001, Hughes et al. 2003), usually manifested as a marked decrease in live coral cover followed by lasting proliferation of algae referred to as a phase shift (Hughes 1994, McCook 1999).

A combination of factors can lead to phase shifts, including widespread coral mortality, declines in herbivory (e.g. die-off of the long-spined urchin Diadema antillarum, overfishing of herbivorous fishes) and localized nutrient enrichment (Hughes 1994, Hunter \& Evans 1995, Szmant 2002). Quantifying the consequences of phase shifts to coral recruitment, growth and competition is critical to the management and restoration of coral reefs. Although the inverse relationship between algal and coral cover on degraded reefs suggests that algae are competitively dominant over adult corals, algal proliferation usually follows coral mortality (reviewed by McCook et al. 2001). This 
may indicate that corals are competitively dominant over algae as adults, but inferior as larvae and recruits (McCook et al. 2001). Experimental evidence for this hypothesized ontogenic shift in competitive advantage of algae over scleractinians is currently lacking.

Larval recruitment is a key process in modulating coral populations (Hughes \& Tanner 2000, Hughes et al. 2003). Coral recruitment is significantly lower in areas that have undergone phase shifts (Edmunds \& Carpenter 2001); however, the mechanisms involved remain unknown. Some studies have shown that filamentous algae or 'algal turfs' can negatively affect survival and growth of juvenile corals (Birkeland 1977, Van Moorsel 1985). Recent experimental studies found that the cyanobacterium Lyngbya majuscula (Kuffner \& Paul 2004) and certain algal turf assemblages (Birrell et al. 2005) can inhibit coral recruitment. Quantifying these effects and identifying the mechanisms involved during these interactions are important steps in investigating the cause and effect relationships responsible for the continuing trend of macroalgal dominance on many reefs today.

In the Florida Keys, coral cover declined from 10.3 to $6.4 \%$ cover (a $38 \%$ relative decline) between 1996 and 2000 (Porter et al. 2002). During this same period, the brown macroalgae Dictyota spp. dominated the benthos at depths between 0 and $25 \mathrm{~m}$ on many of these reefs, covering up to $56 \%$ of the bottom during the summer months (Lirman \& Biber 2000, Beach et al. 2003). Dictyota spp. are now a dominant component of the benthos throughout the Caribbean (Rogers et al. 1997, Williams \& Polunin 2001, Edmunds 2002). In addition, benthic cyanobacteria are occasionally abundant on reefs, periodically blooming on reefs in Florida (Paul et al. 2005), multiple reefs in the Caribbean (Ritson-Williams et al. 2005), Guam (Nagle \& Paul 1998, Thacker \& Paul 2001) and Australia (Dennison et al. 1999); in the latter 2 locations they regularly cause considerable health and economic problems. Cyanobacteria have different ecological roles than macroalgae; because they can fix atmospheric nitrogen, their growth may be limited by other nutrients, such as phosphorus or iron (Paerl 1990, Fong et al. 1993, Kuffner \& Paul 2001), and their modes of reproduction and dispersal differ from those of macroalgae.

Because of their proven chemical deterrence to generalist herbivores (Paul et al. 2001) and their propensity to become spatially dominant on coral reefs around the world, we tested Dictyota spp., Lyngbya spp., Lobophora variegata (J. V. Lamouroux) Womersley and Chondrophycus poiteaui (J. V. Lamouroux) Nam (formerly Laurencia poiteaui) for their effects on coral recruitment and spat survival using manipulative field and outdoor seawater table experiments. We conducted our study in the Florida Keys because the decline in coral cover and predominance of macroalgae make it an appropriate location for investigating the potential inhibition of coral recruitment on algae-dominated coral reefs. We hypothesized that exposure of coral larvae to the selected algal and cyanobacterial species herein collectively referred to as 'macrophytes' increases larval mortality, alters larval behavior (e.g. location of recruitment), inhibits coral recruitment and/or reduces recruit survival. Our controlled, manipulative experiments showed that these locally and regionally common species of macroalgae and cyanobacteria inhibited successful recruitment of the scleractinian Porites astreoides and the octocoral Briareum asbestinum, 2 coral species that are widely distributed throughout the Caribbean.

\section{MATERIALS AND METHODS}

The study, based at the Keys Marine Laboratory, Long Key, Florida, was conducted from May 11 to June 9, 2004 and May 7 to 31, 2005. We examined the effect of several species of algae and cyanobacteria on larval recruitment and recruit survival of the common reef coral Porites astreoides and on the larval settlement of the gorgonian Briareum asbestinum. These coral species were chosen because of their abundance on the reefs in Florida and for the availability of their larvae.

We conducted quantitative abundance and biomass surveys of algae and cyanobacteria at 3 inshore reef areas: '11-Foot Mound' $\left(24^{\circ} 43.381^{\prime} \mathrm{N}, 80^{\circ} 51.696^{\prime} \mathrm{W}\right)$, 'Coral Gardens' $\left(24^{\circ} 50.229^{\prime} \mathrm{N}, 80^{\circ} 43.769^{\prime} \mathrm{W}\right)$, and the 'Tennessee Light CARICOMP' site $\left(24^{\circ} 45.142^{\prime} \mathrm{N}\right.$, $80^{\circ} 45.696^{\prime} \mathrm{W}$ ). To estimate percent cover of algae and benthic invertebrates and the available space that coral larvae could potentially colonize, we placed a $25 \times 25 \mathrm{~cm}$ grid (a quadrat strung with line to produce 25 boxes) on the substrate in selected locations. Number of fin kicks and compass headings were randomly generated using a random numbers table, and percent cover was visually estimated counting the number of boxes (a quarter of a box $=1 \%$ cover) occupied by each species of algae. Suitable settlement substrate (SSS) was defined here as hard substrate with open patches of crustose coralline algae (known settlement cue for some coral larvae; Morse et al. 1988, Heyward \& Negri 1999) devoid of macroalgae, dense turf algae, invertebrates or sediments $>1 \mathrm{~mm}$ thick. Measurement of this benthic category was intended as an index of potential habitat for larval recruitment. Biomass surveys were conducted by haphazardly placing $50 \times 50 \mathrm{~cm}$ quadrats on the reef, harvesting all macrophytes within the plot, separating the samples by species, and determining wet and dry $\left(60^{\circ} \mathrm{C}\right.$ for $\left.48 \mathrm{~h}\right)$ weights.

We collected 40 colonies of the brooding coral Porites astreoides from on and near the pilings of the 
'Seven-Mile Bridge', transported these to the Keys Marine Laboratory in coolers, and maintained them in running seawater. Larvae were collected during the nights of May 14 to 20, 2004 (new moon = May 19) and May 8 to 14, 2005 (new moon = May 8). After enough larvae had been gathered $(\approx 25000)$ to complete the experiments, the colonies were returned to the sites of collection and re-attached to the reef with Z-Spar ${ }^{\circledR}$ A-788 Splash Zone Compound underwater epoxy. To obtain larvae, each colony was placed in an individual 31 Rubbermaid ${ }^{\circledR}$ 'Grip 'N Mix'TM bowl constantly supplied with running seawater. The bowls were tilted such that the positively buoyant larvae spilled over the handles of the bowls into plastic beakers fitted with a $180 \mu \mathrm{m}$ (larvae were $\approx 1 \mathrm{~mm}$ diam.) mesh bottom supported $3 \mathrm{~cm}$ off the tank floor by attached silicone stop-

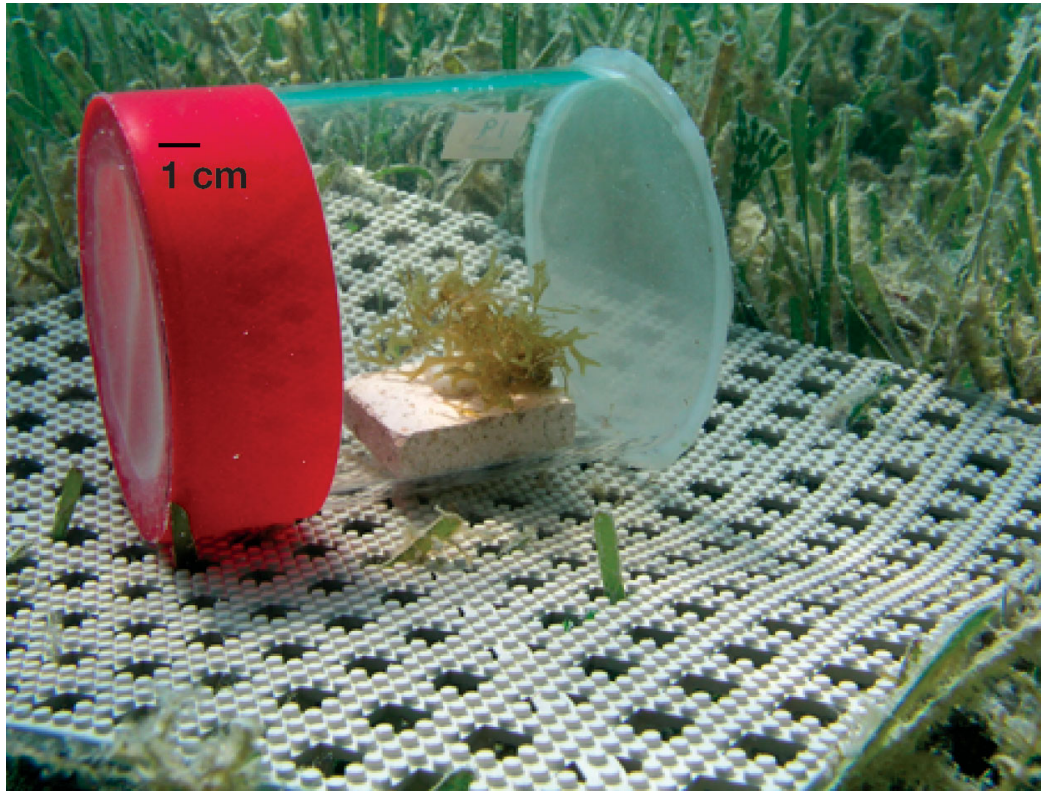

Fig. 1. Larval recruitment chamber $(10.2 \mathrm{~cm}$ diam. $\times 12.7 \mathrm{~cm}$ long $)$ with attached stabilizing mat deployed at $1.5 \mathrm{~m}$ depth. Mesh size $=180 \mu \mathrm{m}$ pers. The water level inside the tank was kept at approximately $15 \mathrm{~cm}$ so that the larvae remained in the beaker traps until they were collected each morning shortly after sunrise. Larvae were pooled into a common container to be subsampled for the experiments.

Porites astreoides larvae were subjected to control and treatment conditions inside customized larval recruitment chambers (Fig. 1). The chambers were deployed in the field, supplying coral larvae with access to suitable settling habitat $(4.5 \times 4.5 \times 1 \mathrm{~cm}$ sections of Sunshine Pavers ${ }^{\circledR}$ wire-cut terracotta tiles conditioned at the Tennessee Light CARICOMP site for $5 \mathrm{wk}$ ) in a contained environment, while allowing water circulation via the $180 \mu \mathrm{m}$ mesh sides, and solar irradiance through the clear, extruded acrylic tubing. The $3.2 \mathrm{~mm}$ thick, $10.2 \mathrm{~cm}$ outer diameter tubing was sliced into $12.7 \mathrm{~cm}$ sections to yield 90 cylindrical chambers fitted with nylon bolts for mounting the settlement tiles. Chambers were deployed at least $1 \mathrm{~m}$ apart, and attached to Dri-Dek ${ }^{\circledR}$ Tiles (rubber mats) with nylon bolts and nuts in order to anchor the chambers upright and parallel to the prevailing currents (Fig. 1).

The relative level of water motion inside the chambers was measured using Life Savers ${ }^{\circledR}$ (wint-o-green ${ }^{\circledR}$ flavor, individually wrapped variety) candies (Koehl $\&$ Alberte 1988). The candies were cable-tied to the nylon posts inside the chambers where the tiles would normally be attached, and to posts that were attached directly to rubber mats without being housed inside a chamber. The mats and mat + chamber assemblies $(n=5)$ were sequentially deployed at the experimental site in a randomized order and left in the water for the candy to dissolve for exactly $10 \mathrm{~min}$ each. A third treatment $(n=5)$ included mats-only assemblies placed in a still bucket filled with seawater for 10 min to measure dissolution rate in the total absence of water motion. The experiment was conducted twice, on May 19 and 20,2005 . The candies were weighed before and after deployment (dried at $60^{\circ} \mathrm{C}$ for at least $24 \mathrm{~h}$ ) to calculate mass (g) lost during deployment. In addition to the candy experiments, nontoxic dye was injected into chambers in the field and in a flume to visualize water moving through the mesh on both ends of the chamber.

Hypothesis: macrophytes affect coral recruitment. To test the hypothesis that selected species of macroalgae and benthic cyanobacteria can inhibit coral recruitment, we conducted 3 experiments using algae collected from the 3 sites from which biomass and percent cover data were gathered. From May 19 to 23, 2004 (Expt 1), larvae were subjected to 4 treatments: control (settlement tile with plastic clip), macrophyte mimic (seawater-conditioned plastic aquarium plant), Dictyota pulchella Hörnig \& Schnetter, or Lobophora variegata (decumbent form) attached to the tile by plastic clips (thin cross sections of PVC pipe split to form a ' $\mathrm{c}$ ' clamp). The plastic aquarium plant was chosen as a mimic because its size, shape and color were comparable to those of the macrophytes tested. From May 21 to 25, 2004 (Expt 2), larvae were subjected to 5 treatments: control, macrophyte mimic, D. pinnatifida Kützing, Lyngbya polychroa (Meneghini) Rabenhorst, or Chondrophycus poiteaui attached to the tile by cable ties. For both Expts 1 and 2, 
there were $\mathrm{n}=10$ replicate chambers per treatment, and each chamber contained 100 larvae. Clumps of algae (roughly $3 \mathrm{~cm}^{3}$ volume) were attached with the plastic clips such that the thalli covered half of the upwardfacing space on the tile. Due to the cylindrical shape of the chamber, the settlement tile did not lie flush with the bottom, allowing larvae easy access to all 6 sides for settlement. Because of foul weather on the reef tract, we placed the chambers in a hard bottom and sparse seagrass community in Florida Bay, directly behind the Keys Marine Laboratory at 1.5 to $2 \mathrm{~m}$ depth. After $4 \mathrm{~d}$, we brought the chambers into the laboratory for analysis. Water inside the chambers was carefully sieved to count larvae still swimming, and the tiles and chambers were inspected under a dissecting microscope to record the number and location of recruits. Total survival was defined as swimming larvae plus live recruits. A recruit was defined as a coral larva that underwent complete metamorphosis, including formation of a calcium carbonate calyx.

Expt 3 was conducted in an outdoor sea table from May 22 to 25, 2004 using the plastic beakers ( $n=6$ per treatment) that were used as traps during larval collection. Porites astreoides larvae were subjected to 4 treatments: control, macrophyte mimic, Dictyota pinnatifida and Lyngbya confervoides C. Agardh. Conditioned settlement tiles were placed on the mesh in each beaker as a substrate for recruitment. Despite lying directly on the mesh, larvae could still easily access the bottom of the tile. The experiment was shaded with neutral density mesh to approximate irradiance levels at 1 to $3 \mathrm{~m}$ depth. Instead of counting the larvae upon placement into the beakers, $50 \mathrm{ml}$ aliquots of water containing the larvae were prepared while constantly stirring the mixture and delivered to each beaker. Because we did not know the actual number of larvae that were placed in each beaker, \% survival or $\%$ recruitment could not be known, so we assumed a normal distribution in number of starting larvae and analyzed counts instead of percents. Beakers were placed in a running seawater table with the water level adjusted to approximately $10 \mathrm{~cm}$ deep. Positions of the beakers within the flume were shifted each day to minimize positional effects.

Recruitment data for all 3 Porites astreoides recruitment experiments were analyzed using 1-way ANOVA with treatment as the fixed factor, and 2-way ANOVA with treatment and position of recruits as the 2 fixed factors. We used a priori contrasts (Student's $t$-tests) of the treatments and the appropriate controls to test explicit hypotheses. When the raw data failed to meet parametric assumptions, they were transformed as specified in 'Results'.

Hypothesis: macrophytes affect recruit survival. Settlement tiles containing live coral recruits from the field experiments were used to test the effects of algal and cyanobacterial contact on recruit survival from May 28 to June 2, 2004 (Expt 4) and May 23 to 28, 2005 (Expt 5). Tiles were haphazardly selected and prepared by removing all but 1 recruit from the top of the tile, and attaching by cable tie either a live algal thallus, a macrophyte mimic (plastic flagging tape), a cable tie only (cable tie control), or nothing (control). In experiment 4 , the live macrophytes tested were Dictyota menstrualis (Hoyt) Schnetter, D. and Lyngbya confervoides. In experiment 5, we tested Chondrophycus poiteaui and Lobophora variegata. The algae were attached so that the thallus was in direct but loose contact with the recruit. Tiles ( $\mathrm{n}=12$ for experiment 4 and $\mathrm{n}=14$ for experiment 5 ) were placed in a running seawater table approximately $50 \mathrm{~cm}$ deep and haphazardly arranged. Shade cloth was placed over the tank to reduce light intensity to levels at 1 to $3 \mathrm{~m}$ depth. Recruit survival data were analyzed using contingency analyses and Fisher exact tests.

Hypothesis: macrophytes affect gorgonian settlement. Briareum asbestinum larvae were obtained by suctioning the surface-brooded larvae off reproductive colonies in the field with a wide-mouth syringe. Expt 6 was conducted from May 31 to June 9, 2004 using the same field chambers as in Expts 1 and 2 ( $\mathrm{n}=10$ per treatment except where noted) and deployed at the same location. Branches of dead gorgonian skeleton were presented as substrate material in lieu of terracotta settlement tiles, which were cable-tied to the nylon bolt; 100 larvae were placed in each chamber. Larvae were subjected to 7 treatments, 6 of which included a piece of gorgonian skeleton (required for metamorphosis cue, M. A. Coffroth pers. comm.): negative control (no skeleton), positive control (gorgonian skeleton only), macrophyte mimic (plastic plant), Dictyota pinnatifida, D. pulchella, Chondrophycus poiteaui and Lyngbya majuscula (Dillwyn) Harvey. Because we did not observe complete metamorphosis of the larvae into polyps with bipinnate tentacles, we considered firm attachment to the substrate as settlement rather than recruitment. Larval survival and settlement data were analyzed using 1-way ANOVA and a priori contrasts.

\section{RESULTS}

Field surveys showed that Dictyota spp. were the most abundant taxa in 2 of the reef areas, covering 39 and $48 \%$ of the benthos at 11-Foot Mound and Tennessee Light, respectively (Fig. 2). Cyanobacteria were generally scarce $(<3 \%$ cover $)$, and suitable settlement substrate was available at all sites but was only abundant at Coral Gardens (31\%, Fig. 2). For 


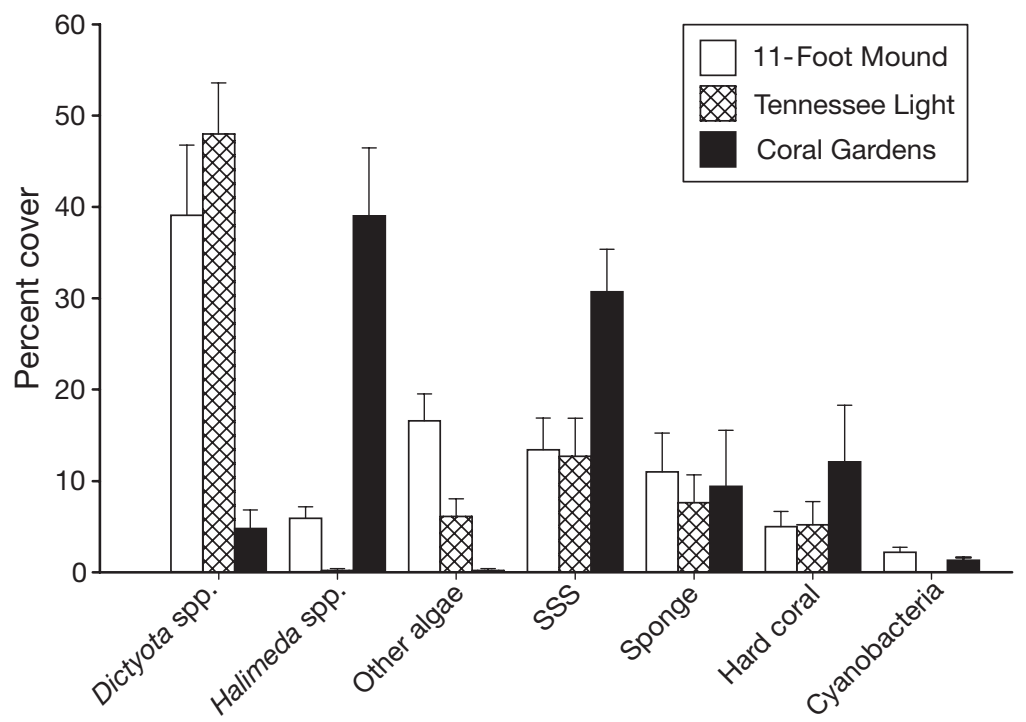

Fig. 2. Mean (+1 SE) percent cover of benthic groups at 3 inshore reef sites off Long Key, Florida Keys. SSS: suitable settlement substrate, defined as hard substrate with patches of crustose coralline algae, devoid of macroalgae, dense turf algae, invertebrates, or sediments $>1 \mathrm{~mm}$ thick

\section{Hypothesis: macrophytes affect coral recruitment}

Algae did not affect larval survival in Expt 1 (Fig. 3A; 1-way ANOVA, p = 0.390). Recruitment, however, was significantly less in the presence of both algal species compared to the macrophyte mimic (1-way ANOVA on square-transformed data, $\mathrm{p}=$ 0.013, a priori contrasts in Fig. 3B), and there was no significant difference between the macrophyte mimic and control $(\mathrm{p}<0.584)$. More larvae recruited to the tile compared to the chamber sides in the control and in the treatment with Dictyota pulchella (position $\times$ treatment interaction: $\mathrm{p}=0.0124$, a priori contrasts in Fig. 3C). Larvae that recruited to the tile recruited proportionally more to the bottom in the control treatment (2-way ANOVA on rank-transformed data, position $\times$ treatment interaction: $\mathrm{p}=0.007$, a priori fleshy algae, the biomass plots were dominated by $D$. menstrualis at Coral Gardens (70 $\pm 25 \mathrm{~g} \mathrm{~m}^{-2}$ dry wt.), and $D$. pulchella at 11-Foot Mound and Tennessee Light $\left(27 \pm 11\right.$ and $74 \pm 25 \mathrm{~g} \mathrm{~m}^{-2}$ dry wt., respectively, Table 1).

The results of the water flow experiments showed that the dissolution of Life Savers ${ }^{\circledR}$ candies was significantly greater in both field treatments (inside and outside of chambers) compared to the still bucket treatment, and there was no significant difference in dissolution inside vs. outside the chambers (2-way ANOVA significant interaction between run and treatment $\mathrm{p}=0.004$, Tukey HSD posthoc multiple comparison of treatments alpha $=0.05$ ). Evidence of the significant interaction term was seen in the difference between the field treatments and the still bucket treatment being greater during the first run when conditions were windier, but the difference between the 2 field treatments was similar in both runs. The dye injection experiments revealed that water could easily move through the mesh, and oscillatory flow generated by wavelets was observed as the dye was sucked back and forth through the chamber.
Table 1. Taxonomic identity and biomass $\left(\mathrm{g} \mathrm{m}^{-2}\right.$ dry $\mathrm{wt}$ mean $\pm \mathrm{SE}$ ) of macrophytes at 3 inshore reef sites off Long Key, Florida Keys. For 11-Foot Mound $n=12$, Tennessee Light $n=6$, Coral Gardens $n=6$

\begin{tabular}{|c|c|c|c|}
\hline Species & 11-Foot Mound & Tennessee Light & Coral Gardens \\
\hline Amphiroa rigida & $0.47 \pm 0.28$ & $0.01 \pm 0.01$ & \\
\hline Avrainvillea sp. & $0.03 \pm 0.03$ & & \\
\hline Botryocladia sp. & $0.03 \pm 0.03$ & & \\
\hline \multicolumn{3}{|l|}{ Chondrophycus } & \\
\hline \multicolumn{4}{|l|}{ Cladophoropsis } \\
\hline membranacea & $58.33 \pm 26.39$ & & \\
\hline Crustose coralline algae & $0.20 \pm 0.20$ & & \\
\hline Dasycladus sp. & $0.10 \pm 0.10$ & & \\
\hline Dictyota caribaea & $1.33 \pm 1.20$ & & \\
\hline Dictyota menstrualis & $0.17 \pm 0.17$ & $0.22 \pm 0.13$ & $70.27 \pm 10.81$ \\
\hline Dictyota pinnatifida & $3.83 \pm 3.21$ & & \\
\hline Dictyota pulchella & $26.80 \pm 11.15$ & $74.13 \pm 25.18$ & $0.67 \pm 0.67$ \\
\hline Galaxura rugosa & $13.35 \pm 3.86$ & $0.31 \pm 0.19$ & \\
\hline Gelidiella sp. & $1.07 \pm 0.79$ & & \\
\hline Halimeda goreaui & $3.57 \pm 2.52$ & $54.24 \pm 45.23$ & \\
\hline Halimeda opuntia & $129.93 \pm 67.23$ & & $811.93 \pm 270.73$ \\
\hline Halimeda tuna & $52.63 \pm 16.94$ & & $545.00 \pm 55.49$ \\
\hline Hypnea sp. & $2.90 \pm 1.37$ & $0.65 \pm 0.17$ & $0.33 \pm 0.33$ \\
\hline Jania sp. & $3.37 \pm 2.30$ & $1.73 \pm 0.76$ & \\
\hline Liagora sp. & $0.40 \pm 0.40$ & & \\
\hline Lobophora variegata & $0.25 \pm 0.20$ & $1.03 \pm 0.44$ & \\
\hline Neomersis annulata & $0.02 \pm 0.01$ & $0.01 \pm 0.01$ & \\
\hline Penicillus capitatus & $0.40 \pm 0.29$ & & \\
\hline Penicillus pyriformis & $4.33 \pm 3.98$ & & \\
\hline Rhipocephalus sp. & $0.20 \pm 0.20$ & & \\
\hline Sargassum sp. & $3.49 \pm 1.49$ & $0.02 \pm 0.02$ & \\
\hline Udotea cyathiformis & $4.27 \pm 1.89$ & $1.07 \pm 0.92$ & \\
\hline Udotea flabellum & $0.07 \pm 0.07$ & & \\
\hline Valonia sp. & & & $0.93 \pm 0.86$ \\
\hline Cyanobacteria & $0.10 \pm 0.10$ & & \\
\hline
\end{tabular}



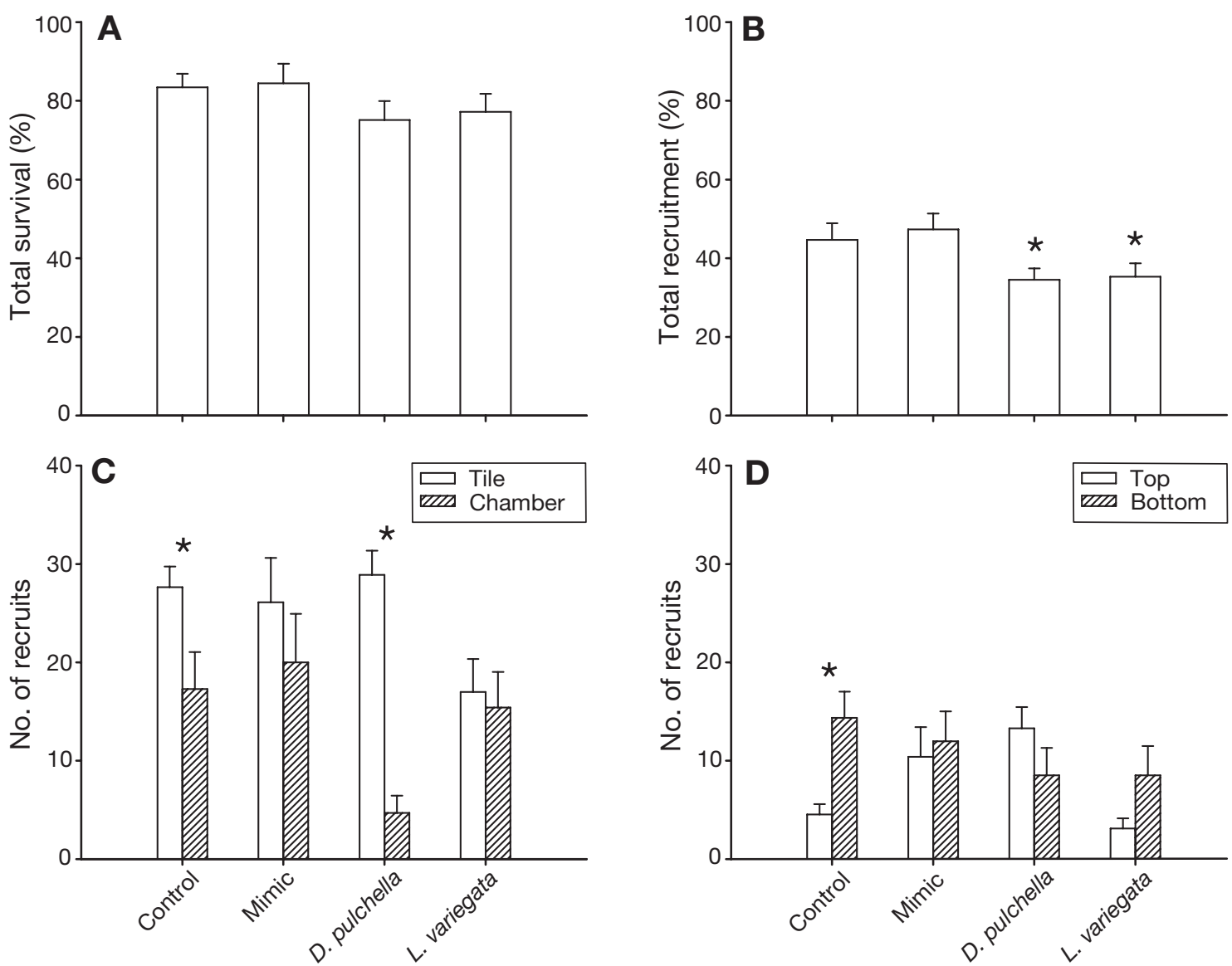

Fig. 3. Porites astreoides. Expt 1. Test of hypothesis that macrophytes affect recruitment, showing mean (+1 SE) percent of larvae in chambers $(n=10)$ that $(A)$ survived (swimmers + recruits), (B) recruited ( $*$ : significant difference [p $<0.05]$ between macrophyte mimic and Dictyota pulchella or Lobophora variegata treatment), (C) recruited to tile vs. chamber sides ( $*$ significant difference [control $\mathrm{p}=0.032, D$. pulchella $\mathrm{p}<0.0001$ ] between tile and chamber sides), and (D) recruited on top vs. bottom of tile ( $*$ : significant difference $[\mathrm{p}=0.004]$ between top and bottom)

contrast in Fig. 3D) and equally to top and bottom of the tiles in the other 3 treatments.

The presence of algae or cyanobacteria did not affect larval survival or total recruitment in Expt 2 (Fig. 4A,B; 1 -way ANOVA $\mathrm{p}=0.460, \mathrm{p}=0.059$, respectively). However, we found that significantly more larvae recruited onto the tile than onto the chamber in the control treatment, while the opposite was true in the Lyngbya polychroa treatment (2-way ANOVA on rank-transformed data, position $\times$ treatment interaction: $\mathrm{p}<0.0001$, a priori contrast in Fig. 4C). When only recruits on the tile were considered, there was proportionally more recruitment to the bottom of the tiles, overall (2-way ANOVA on rank-transformed data, position: $p<0.0001$, treatment: $p=0.004$, treatment $\times$ position: $\mathrm{p}=0.223$ ). The proportion of larvae recruiting onto the top of the tile out of total recruitment onto the tile was significantly lower in the presence of L. polychroa compared to the macrophyte mimic (1-way ANOVA on arcsine-transformed proportions: $\mathrm{p}=0.006$, a priori contrast: $\mathrm{p}=0.001$; Fig. 4D).
The presence of macrophytes did not significantly affect the total number of live larvae (Fig. 5A, 1-way ANOVA, $p=0.078$ ) or total recruitment (Fig. 5B, 1-way ANOVA, $p=0.110$ ) in Expt 3. We found no larvae recruited to the beaker sides or mesh. Despite an overall pattern of more recruitment to tile bottoms (Fig. 5C), a greater proportion of larvae recruited to the top of the tile in the macrophyte mimic compared to treatments with Dictyota pinnatifida, Lyngbya confervoides and in the control (1-way ANOVA: $\mathrm{p}=0.001$, a priori contrasts in Fig. 5D).

\section{Hypothesis: macrophytes affect recruit survival}

Recruit survival was significantly affected by the presence of the macrophytes tested in Expt 4 (contingency analysis Pearson chi square $p<0.0001$ ). All 12 replicate recruits survived in the control and cable tie treatments, and 2 died in the macrophyte mimic treatment. Only 2 recruits survived with Dictyota 

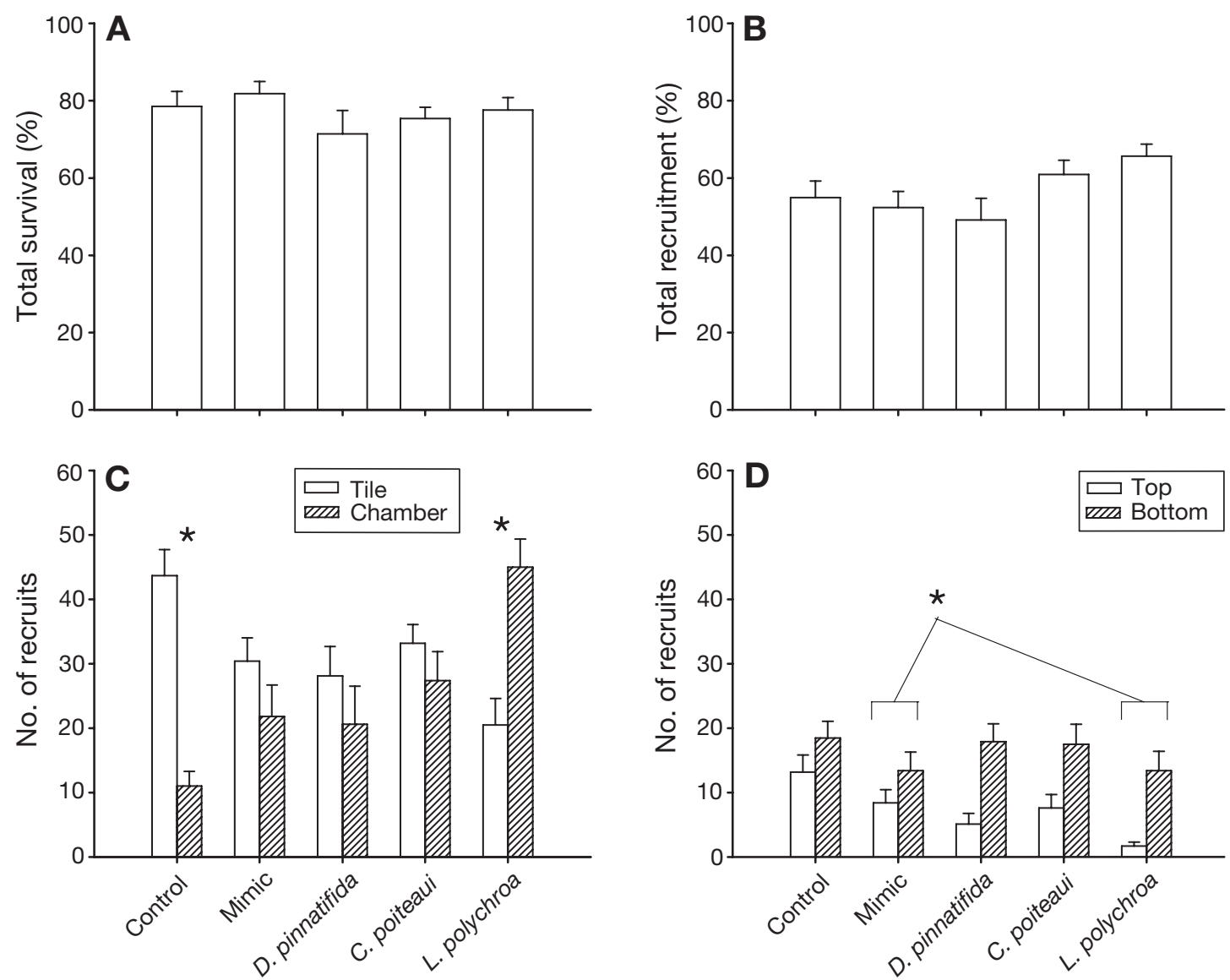

Fig. 4. Porites astreoides. Expt 2. Test of hypothesis that macrophytes affect recruitment, showing mean (+1 SE) percent of larvae in chambers $(\mathrm{n}=10)$ that $(\mathrm{A})$ survived (swimmers + recruits), $(\mathrm{B})$ recruited, $(\mathrm{C})$ recruited to tile vs. chamber sides $(\star$ : significant difference $[p<0.05]$ between tile and chamber sides), and (D) recruited to top vs. bottom of tile ( $*$ : significant difference $[\mathrm{p}=0.001]$ in proportion of larvae recruiting on top of tile). L. polychroa: Lyngbya polychroa; C. poiteaui: Chondrophycus poiteaui; D. pinnatifida: Dictyota pinnatifida

menstrualis (significantly lower than macrophyte mimic, Fisher exact test, $\mathrm{p}=0.003$ ) and none survived in the Lyngbya confervoides treatment $(\mathrm{p}<0.0001)$. Survival was also low (4 survivors) with $D$. pulchella (compared to the macrophyte mimic, Fisher exact test, $\mathrm{p}=0.036$ ). All comparisons except $D$. pulchella satisfy a Bonferroni adjustment for multiple tests. In Expt 5, recruit survival was not significantly affected by treatment (contingency analysis Pearson chi square $\mathrm{p}=$ 0.86); 1 recruit out of 14 died in the cable-tie control and macrophyte mimic treatments (plain tile control was eliminated in this experiment), and 2 out of 14 died in each of the Chondrophycus poiteaui or Lobophora variegata treatments.

\section{Hypothesis: macrophytes affect gorgonian settlement}

Overall survival and settlement were much lower for Briareum asbestinum than for Porites astreoides, with an overall survival rate of $25.3 \pm 1.2 \%$ and $2.0 \pm 0.3 \%$ successfully settling. However, survival was significantly higher in control chambers than in chambers with gorgonian skeleton only, and significantly lower in Lyngbya majuscula chambers compared to the macrophyte mimic (1-way ANOVA: $\mathrm{p}<0.001$, a priori contrasts in Fig. 6A). Settlement was significantly higher when gorgonian skeleton was present than in the negative control, and significantly lower in the presence of $L$. majuscula than in the macrophyte mimic (1-way ANOVA on rank-transformed data: $\mathrm{p}=$ 0.024, a priori contrasts in Fig. 6B).

\section{DISCUSSION}

We have presented evidence that locally common species of algae and cyanobacteria deter coral larvae from recruiting nearby despite the availability of suitable settlement substrate; most of the species we tested affected the location of coral recruitment. Our macrophyte mimics had positive effects on recruitment (probably due 

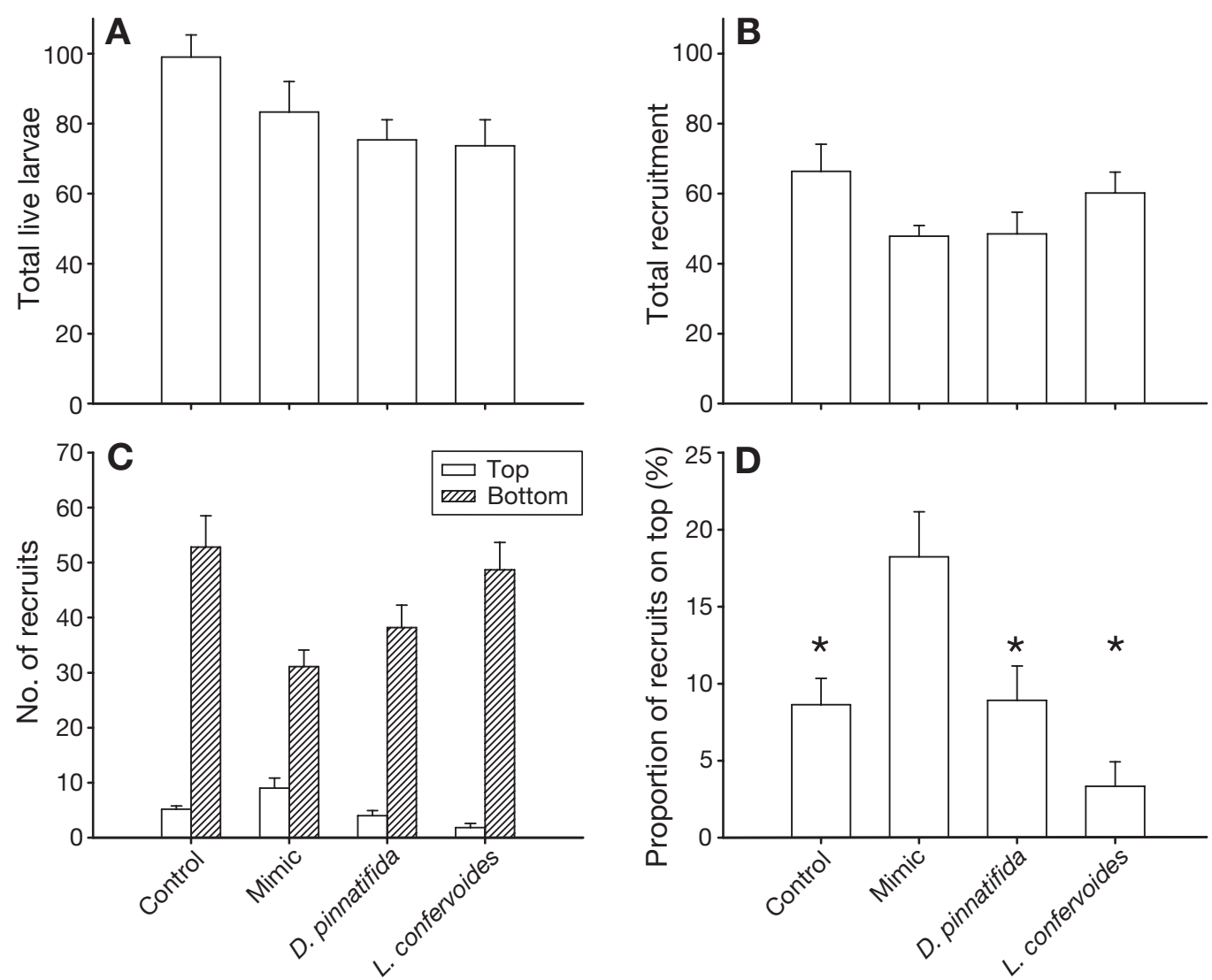

Fig. 5. Porites astreoides. Expt 3. Test of hypothesis that macrophytes affect recruitment, showing mean (+1 SE) number of larvae in mesh-bottomed beakers $(n=6)$ that $(A)$ survived (swimmers + recruits), (B) recruited, and $(C)$ recruited to top vs. bottom of tile. (D) Percent of total recruits found on top of tile ( $*$ : significant difference between macrophyte mimic and the control $[\mathrm{p}=0.006]$, Dictyota pinnatifida $[\mathrm{p}=0.007]$, or Lyngbya confervoides $[\mathrm{p}=0.0001]$ treatment $)$

to shading and creation of cryptic habitat), and selected species of live macrophytes had negative effects that counteracted the positive effects created by an algal canopy. Furthermore, some of these macrophytes caused increased mortality rates when in contact with coral recruits. Our results show that these macroalgae and cyanobacteria can inhibit coral recruitment beyond actual space occupation, presenting a mechanism by which abundant macrophytes can perpetuate phase shifts by reducing local coral recruitment.

Porites astreoides larvae were deterred from recruiting to the tile by the presence of Dictyota, Lyngbya and Lobophora species. We observed species-specific effects on multiple components of recruitment including total number of recruits, recruitment location and recruit survival. D. pulchella and Lobophora variegata decreased overall recruitment compared to the macrophyte mimic, while $D$. pinnatifida, Lyngbya polychroa and $L$. confervoides affected the location of recruitment, suggesting that larvae avoid these species. Since benthic cover by Dictyota spp. approaches $50 \%$ on many reefs in the Florida Keys, the potential for these algae to reduce coral recruitment is considerable.
In a previous study examining the effects of cyanobacteria on scleractinian coral recruitment in Guam, Kuffner \& Paul (2004) found that the presence of Lyngbya majuscula had a negative effect on larval survival for Acropora surculosa (broadcast spawner) and recruitment of Pocillopora damicornis (brooder). They also observed an avoidance behavior in the brooding species similar to that we observed in Porites astreoides. In our study, L. majuscula reduced survival and settlement of Briareum asbestinum larvae, and both L. polychroa and $L$. confervoides affected the recruitment location of $P$. astreoides, but not larval survival or total recruitment. The species-specific effects revealed in this study illustrate the complexity of algae-coral interactions and their potential impact on community dynamics.

Larvae are known to respond to both positive chemical cues associated with crustose coralline algae (Morse et al. 1988, Heyward \& Negri 1999) and negative physical cues such as sediment (Hodgson 1990, Babcock \& Davies 1991, Gilmour 1999) and ultraviolet radiation (Kuffner 2001, Gleason et al. 2006). Our results suggest that Porites astreoides larvae may use certain macroalgae and cyanobacteria as negative 

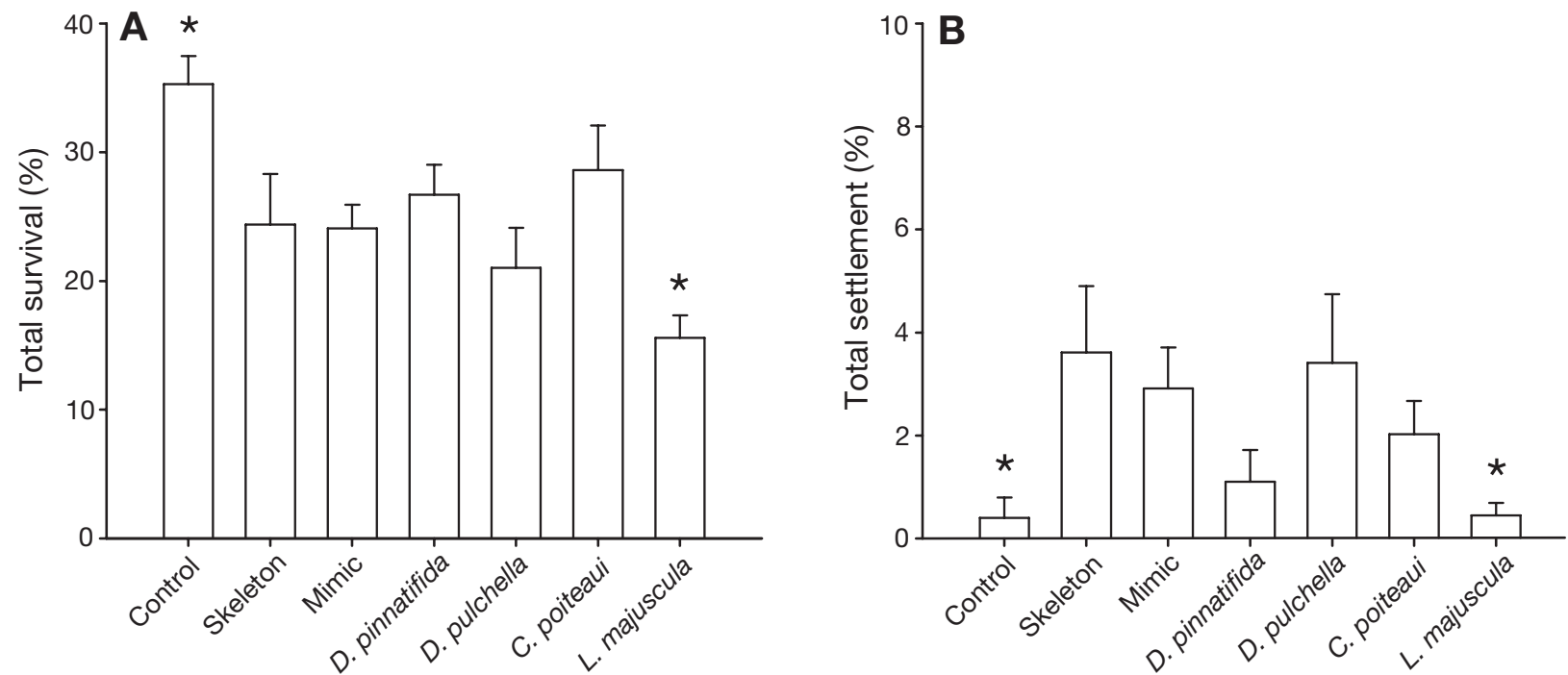

Fig. 6. Briareum asbestinum. Expt 6. Test of hypothesis that macrophytes affect settlement, showing mean (+1 SE) percent of larvae in chambers $(\mathrm{n}=10$, except for Chondrophycus poiteaui where $\mathrm{n}=11$, and Lyngbya majuscula where $\mathrm{n}=9$ ) that $(\mathrm{A})$ survived (swimmers + settlers; * : significant difference between negative control and skeleton [ $p=0.008]$, and macrophyte mimic and L. majuscula [p =0.043]), and (B) settled ( $*$ : significant difference between negative control and skeleton [p $=0.011]$ and macrophyte mimic and L. majuscula $[\mathrm{p}=0.029])$. D. pinnatifida: Dictyota pinnatifida; $D$. pulchella: Dictyota pulchella

settlement cues. Baird \& Morse (2004) showed similar effects of Lobophora sp. on the brooded planulae of Acropora palifera and Stylophora pistillata and suggested allelopathy as the mechanism. Similarly, Maida et al. (1995) showed allelopathic effects for 2 species of soft corals on scleractinian recruitment. However, an alternative to allelopathy is the hypothesis that pathogens associated with the algae are responsible for the observed negative effect (Nugues et al. 2004b).

Our study also showed evidence of positive settlement cues; Porites astreoides larvae clearly preferred the biologically conditioned tile to the chamber sides, even though the tile comprised only $10 \%$ of the total area available. A positive effect of shade was also suggested by our experiments. A higher proportion of larvae recruited to the bottom of the tile in the controls compared to the mimic (which provided shade) in Expts 1 and 3, and in both experiments using chambers (Expts 1 and 2), larvae that recruited to the chamber sides were overwhelmingly found in the shade provided by the chamber lid (data not shown). It is unclear why we did not see a positive effect of the mimic in Expt 2, but it is possible that irradiance levels were lower during this experiment due to increased turbidity (reversal of tidal direction during the day) or cloud cover. Coral larvae are known to recruit to the shaded undersides of recruitment tiles in shallow, high-irradiance conditions (Birkeland et al. 1981, Maida et al. 1994). In addition, in our study there was a significant positive effect of gorgonian skeleton on Briareum asbestinum settlement, similar to the documented effect of crustose coralline algae on sclerac- tinian larvae (Morse et al. 1988, Heyward \& Negri 1999). Evidence for the complexity and selectiveness of larval choice in substrate habitat continues to mount, showing that coral recruitment patterns are speciesspecific and coral larvae are highly attuned to their preferred habitat (Baird et al. 2003).

Because of the difficulty in finding very small juvenile corals in the field and the logistics of long-term recruitment studies, there is a gap in our knowledge regarding post-recruitment survival. In this study, survival of Porites astreoides recruits was significantly reduced (compared to the plastic flagging tape macrophyte mimic) when the recruits were placed in contact with Dictyota menstrualis and Lyngbya confervoides. Thus, it appears that these species can kill coral recruits using mechanisms other than simple shading or abrasion. As the juvenile coral reaches a certain threshold size, defense mechanisms on the part of the coral may come into play, such as the use of mesenterial filaments in reducing the growth and damaging the thalli of neighboring algae (Nugues et al. 2004a). It remains unknown how old corals have to be to employ these tactics, but apparently adult $P$. astreoides do not use this defense mechanism against algae (Nugues et al. 2004a). Lirman (2001) found that the growth of adult $P$. astreoides and Montastrea annularis was reduced when caged with Dictyota spp. Similarly, an algal clearance experiment demonstrated that coral growth (Acropora cuneata and A. palifera) and fecundity (A. palifera) were increased by algal removal (Tanner 1995). Thus, it is clear that coral-algae interactions can be metabolically expensive for some species of coral. 
Available data on Dictyota spp. and cyanobacteria show that these taxa can colonize large areas on reefs. Dictyota spp. in the Florida Keys can propagate rapidly by vegetative fragmentation resulting from storms (Vroom et al. 2005) and fish foraging (Herren et al. 2006). Under certain conditions, benthic cyanobacteria can also spread rapidly and form blooms covering $>50 \%$ of the substrate (Dennison et al. 1999, Thacker \& Paul 2001). Species of Dictyota and Lyngbya are chemically rich and are generally unpalatable to most generalist grazers (Thacker et al. 1997, Nagle \& Paul 1998, Paul et al. 2001), probably facilitating the formation of blooms on coral reefs. Many secondary metabolites have multiple functions (Becerro et al. 1997, Paul et al. 2001), so it is conceivable that anti-herbivory compounds are responsible for the inhibition of coral recruitment and survival observed in this study.

Further investigation into the mechanisms behind the effects observed in this study are a critical next step in determining if allelopathic interactions between benthic primary producers and coral larvae could be perpetuating phase shifts on coral reefs. While studies have shown that coral mortality, reduced herbivory and increased nutrient availability can act in concert to cause phase shifts, few have investigated the mechanisms responsible for the maintenance of high algal cover on disturbed reefs. By showing that algae and cyanobacteria can inhibit coral recruitment, we have identified 1 mechanism that could be preventing the recovery of coral reef communities.

Acknowledgements. This research was funded by a US Geological Survey State Partnership Program grant with matching funds from the University of Central Florida to I.B.K., L.J.W., V.J.P. and K.S.B. M.A.B. was supported by a grant to V.J.P. from the Florida Center of Excellence in Biomedical and Marine Biotechnology. We thank L. Tipsword (Director) and the Keys Marine Laboratory staff for their hospitality and assistance in the field, particularly C. Humphries and L. Giles for deploying the tiles for conditioning. Thanks also go to S. Duran and K. Brown for help with the execution of the experiments, A. Erickson for assistance with identification of the cyanobacteria used in this study, and M. A. Coffroth's group for scholarly interaction and cooperation in the field. Comments from C. S. Rogers, G. A. Piniak, P. J. Edmunds and 5 anonymous reviewers greatly improved the manuscript. This research was conducted under National Marine Sanctuary Permit FKNMS-2004-018. This manuscript is contribution no. 632 from the Smithsonian Marine Station at Fort Pierce and no. P200601 from the Florida Center of Excellence in Biomedical and Marine Biotechnology. Any use of trade names is for descriptive purpose only and does not imply endorsement by the US Government.

\section{LITERATURE CITED}

Babcock R, Davies P (1991) Effects of sedimentation on settlement of Acropora millepora. Coral Reefs 9:205-208

Baird AH, Morse ANC (2004) Induction of metamorphosis in larvae of the brooding corals Acropora palifera and Stylophora pistillata. Mar Freshw Res 55:469-472

Baird AH, Babcock RC, Mundy CP (2003) Habitat selection by larvae influences the depth distribution of six common coral species. Mar Ecol Prog Ser 252:289-293

Beach K, Walters L, Borgeas H, Smith C, Coyer J, Vroom P (2003) The impact of Dictyota spp. on Halimeda populations of Conch Reef, Florida Keys. J Exp Mar Biol Ecol 297:141-159

Becerro MA, Uriz MJ, Turon X (1997) Chemically-mediated interactions in benthic organisms: the chemical ecology of Crambe crambe (Porifera, Poecilosclerida). Hydrobiologia 356:77-89

Benayahu Y, Loya Y (1981) Competition for space among coral-reef sessile organisms at Eilat, Red Sea. Bull Mar Sci 31:514-522

Birkeland C (1977) The importance of rate of biomass accumulation in early successional stages of benthic communities to the survival of coral recruits. Proc 3rd Int Coral Reef Symp, Miami 1:15-21

Birkeland C, Rowley D, Randall R (1981) Coral recruitment patterns at Guam. Proc 4th Int Coral Reef Symp, Manila 2:339-344

Birrell CL, McCook LJ, Willis BL (2005) Effects of algal turfs and sediment on coral settlement. Mar Pollut Bull 51: 408-414

Dahl AL (1974) The structure and dynamics of benthic algae in the coral reef ecosystem. Proc 2nd Int Coral Reef Symp, Brisbane, 21-25

Dennison WC, O'Neil JM, Duffy EJ, Oliver PE, Shaw GR (1999) Blooms of the cyanobacterium Lyngbya majuscula in coastal waters of Queensland, Australia. Bull Inst Océanogr 19:501-506

Edmunds PJ (2002) Long-term dynamics of coral reefs in St. John, US Virgin Islands. Coral Reefs 21:357-367

Edmunds PJ, Carpenter RC (2001) Recovery of Diadema antillarum reduces macroalgal cover and increases abundance of juvenile corals on a Caribbean reef. Proc Natl Acad Sci USA 98:5067-5071

Fong P, Zedler JB, Donohoe RM (1993) Nitrogen vs. phosphorus limitation of algal biomass in shallow coastal lagoons. Limnol Oceanogr 38:906-923

Gilmour J (1999) Experimental investigation into the effects of suspended sediment on fertilisation, larval survival and settlement in a scleractinian coral. Mar Biol 135:451-462

Gleason DF, Edmunds PJ, Gates RD (2006) Ultraviolet radiation effects on the behavior and recruitment of larvae from the reef coral Porites astreoides. Mar Biol 148:503-512

Herren LW, Walters LJ, Beach KS (2006) Fragment generation, survival, and attachment of Dictyota spp. at Conch Reef, Florida Keys. Coral Reefs 25:287-295

Heyward AJ, Negri AP (1999) Natural inducers for coral larval metamorphosis. Coral Reefs 18:273-279

Hodgson G (1990) Sediment and the settlement of larvae of the reef coral Pocillopora damicornis. Coral Reefs 9:41-43

Hoegh-Guldberg O (1999) Climate change, coral bleaching and the future of the world's coral reefs. Aust J Mar Freshw Res 50:839-866

Hughes TP (1994) Catastrophes, phase shifts, and largescale degradation of a Caribbean coral reef. Science 265: $1547-1551$

Hughes TP, Tanner JE (2000) Recruitment failure, life histories, and long-term decline of Caribbean corals. Ecology 81:2250-2263

Hughes TP, Baird AH, Bellwood DR, Card M and 13 others (2003) Climate change, human impacts, and the resilience of coral reefs. Science 301:929-933 
Hunter CL, Evans CW (1995) Coral reefs in Kaneohe Bay, Hawaii: two centuries of western influence and two decades of data. Bull Mar Sci 57:501-515

Jackson JBC, Buss L (1975) Allelopathy and spatial competition among coral reef invertebrates. Proc Natl Acad Sci USA 72:5160-5163

Knowlton N (2001) The future of coral reefs. Proc Natl Acad Sci USA 98:5419-5425

Koehl MAR, Alberte RS (1988) Flow, flapping, and photosynthesis of Nereocystis luetkeana: a functional comparison of undulate and flat blade morphologies. Mar Biol 99:435-444

Kuffner IB (2001) Effects of ultraviolet radiation on larval recruitment of the reef coral, Pocillopora damicornis. Mar Ecol Prog Ser 217:251-261

Kuffner IB, Paul VJ (2001) Effects of nitrate, phosphate and iron on the growth of macroalgae and benthic cyanobacteria from Cocos Lagoon, Guam. Mar Ecol Prog Ser 222:63-72

Kuffner IB, Paul VJ (2004) Effects of the benthic cyanobacterium Lyngbya majuscula on larval recruitment of the reef corals Acropora surculosa and Pocillopora damicornis. Coral Reefs 23:455-458

Lirman D (2001) Competition between macroalgae and corals: effects of herbivore exclusion and increased algal biomass on coral survivorship and growth. Coral Reefs 19: 392-399

Lirman D, Biber P (2000) Seasonal dynamics of macroalgal communities of the northern Florida reef tract. Bot Mar 43: 305-314

Maida M, Coll JC, Sammarco PW (1994) Shedding new light on scleractinian coral recruitment. J Exp Mar Biol Ecol 180:189-202

Maida M, Sammarco PW, Coll JC (1995) Effects of soft corals on scleractinian coral recruitment. I: Directional allelopathy and inhibition of settlement. Mar Ecol Prog Ser 121: 191-202

McCook LJ (1999) Macroalgae, nutrients and phase shifts on coral reefs: scientific issues and management consequences for the Great Barrier Reef. Coral Reefs 18:357-367

McCook LJ, Jompa J, Diaz-Pulido G (2001) Competition between corals and algae on coral reefs: a review of evidence and mechanisms. Coral Reefs 19:400-417

Morse DE, Hooker N, Morse ANC, Jensen RA (1988) Control of larval metamorphosis and recruitment in sympatric agariciid corals. J Exp Mar Biol Ecol 116:193-217

Nagle DG, Paul VJ (1998) Chemical defense of a marine cyanobacterial bloom. J Exp Mar Biol Ecol 255:29-38

Nugues MM, Delvoye L, Bak RPM (2004a) Coral defence against macroalgae: differential effects of mesenterial filaments on the green alga Halimeda opuntia. Mar Ecol Prog Ser 278:103-114

Nugues MM, Smith GW, Van Hooindonk RJ, Seabra MI, Bak RPM (2004b) Algal contact as a trigger for coral disease. Ecol Lett 7:919-923

Editorial responsibility: Charles Birkeland (Contributing Editor), Honolulu, Hawaii, USA
Paerl HW (1990) Physiological ecology and regulation of $\mathrm{N}_{2}$ fixation in natural waters. Adv Microb Ecol 11: 305-344

Paul VJ, Cruz-Rivera E, Thacker RW (2001) Chemical mediation of macroalgal-herbivore interactions: ecological and evolutionary perspectives. In: McClintock JB, Baker BJ (eds) Marine chemical ecology. CRC Press, Boca Raton, FL, p 227-265

Paul VJ, Thacker RW, Banks K, Golubic S (2005) Benthic cyanobacterial bloom impacts the reefs of South Florida (Broward County, USA). Coral Reefs 24:693-697

Porter JW (1974) Community structure of coral reefs on opposite sides of the Isthmus of Panama. Science 186:543-545

Porter JW, Targett NM (1988) Allelochemical interactions between sponges and corals. Biol Bull (Woods Hole) 175: $230-239$

Porter JW, Kosmynin V, Patterson KL, Porter KG and 13 others (2002) Detection of coral reef change by the Florida Keys Coral Reef Monitoring Project. In: Porter JW, Porter KG (eds) The Everglades, Florida Bay, and coral reefs of the Florida Keys: an ecosystem sourcebook. CRC Press, Boca Raton, FL, p 749-769

Ritson-Williams R, Paul VJ, Bonito V (2005) Marine benthic cyanobacteria overgrow coral reef organisms. Coral Reefs $24: 629$

Rogers CS, Garrison V, Grober-Dunsmore R (1997) A fishy story about hurricanes and herbivory: seven years of research on a reef in St. John, US Virgin Islands. Proc 8th Int Coral Reef Symp, Panama 1:555-560

Szmant AM (2002) Nutrient enrichment on coral reefs: is it a major cause of coral reef decline? Estuaries 25:743-766

Tanner JE (1995) Competition between scleractinian corals and macroalgae: an experimental investigation of coral growth, survival and reproduction. J Exp Mar Biol Ecol 190:151-168

Thacker RW, Paul VJ (2001) Are benthic cyanobacteria indicators of nutrient enrichment? Relationships between cyanobacterial abundance and environmental factors on the reef flats of Guam. Bull Mar Sci 69:497-508

Thacker RW, Nagle DG, Paul VJ (1997) Effects of repeated exposures to marine cyanobacterial secondary metabolites on feeding by juvenile rabbitfish and parrotfish. Mar Ecol Prog Ser 147:21-29

Van Moorsel GWNM (1985) Disturbance and growth of juvenile corals (Agaricia humilis and Agaricia agaricites, Scleractinia) in natural habitats on the reef of Curacao. Mar Ecol Prog Ser 24:99-112

Vroom P, Walters L, Beach K, Coyer J and 12 others (2005) Hurricane induced propagation and rapid regrowth of the weedy brown alga Dictyota in the Florida Keys. Fla Sci 68: 161-174

Williams ID, Polunin NVC (2001) Large-scale associations between macroalgae cover and grazer biomass on middepth reefs in the Caribbean. Coral Reefs 19:358-366

Submitted: August 7, 2005; Accepted: January 27, 2006

Proofs received from author(s): September 11, 2006 